\title{
The Psychology of Climate Anxiety - ERRATUM
}

Joseph Dodds

BJPsych Bulletin (2021) 45, 256-256, doi:10.1192/bjb.2021.58

(c) The Author(s), 2021. Published by Cambridge University Press on behalf of the Royal College of Psychiatrists. This is an Open Access article, distributed under the terms of the Creative

Commons Attribution-NonCommercialShareAlike licence (http://

creativecommons.org/licenses/by-ncsa/4.0/), which permits non-

commercial re-use, distribution, and reproduction in any medium, provided the same Creative Commons licence is included and the original work is

properly cited. The written permission of

Cambridge University Press must be

obtained for commercial re-use.

DOI: https://doi.org/10.1192/bjb.

2021.18, Published by Cambridge

University Press, 19th May 2021
Keywords Climate anxiety; climate change; psychoanalysis; post-traumatic stress disorder; ecological trauma, erratum.

This article was originally published with an incorrect affiliation for Joseph Dodds. Dr Dodds is solely affiliated with Psychology Faculty, University of New York in Prague, Czech Republic.

\section{Reference}

Dodds J. The psychology of climate anxiety. BJPsych Bull 2021; 1-5. doi: 10.1192/bjb.2021.18. 